\title{
Use of a continuously recording intravascular oxygen electrode in the newborn
}

\author{
P. GODDARD, I. KEITH, H. MARCOVITCH,* N. R. C. ROBERTON, P. ROLFE, and \\ J. W. SCOPES† \\ From the Neonatal Department, Institute of Child Health, Hammersmith Hospital, London, and the Department \\ of Paediatrics, John Radcliffe Hospital, Headington, Oxford
}

Goddard, P., Keith, I., Marcovitch, H., Roberton, N. R. C., Rolfe, P., and Scopes, J. W. (1974). Archives of Disease in Childhood, 49, 853. Use of a continuously recording intravascular oxygen electrode in the newborn. The use of a continuously recording intravascular $\mathrm{Po}_{2}$ electrode is described. The electrode, based on the Galvanic principle, is built into the tip of a French gauge (FG) 5 umbilical arterial catheter. Its use has considerably improved the management of oxygen therapy in the seriously ill premature newborn infant and has done so with at least a $50 \%$ reduction in the amount of blood needed to be removed for gas analysis.

Frequent measurement of arterial oxygen tensions is an essential part of the management of oxygen therapy in low birthweight infants with pulmonary disease, thus avoiding the danger of hypoxia and oxygen toxicity (Roberton et al., 1968; Scopes, 1971; Davies et al., 1972; Banerjee, Girling, and Wigglesworth, 1972). Orthodox monitoring of such babies is to sample umbilical arterial blood from an indwelling catheter at least 4-hourly. The $\mathrm{PaO}_{2}$ needs to be checked more frequently whenever therapy is changed, and in particular when some form of continuous distending pressure (Gregory $e t$ al., 1971; Chernick and Vidyasagar, 1972; Dunn, Speidel, and Storrs, 1973; Fanaroff et al., 1973) is applied to the lungs or positive pressure ventilation is instituted. Though samples of only $200-300 \mu 1$ are needed, the total blood loss in the course of a few days' illness is considerable.

Veasey et al. (1971) described computerized on-line real-time analysis (CABAS), which in the first infant studied resulted in a $3.8 \mathrm{~kg}$ baby having 349 arterial samples taken during a 12 -day period at a mean interval of 49 minutes. This system has the disadvantages of necessitating frequent restorative blood transfusions and of being extremely costly.

\footnotetext{
Received 8 April 1974.

*Percy J. Neate Fellow of the Worshipful Company of Clothworkers. Present address: Clinical Research Centre, Northwick Park Hospital, Harrow.

†Present address: Department of Paediatrics, St. Thomas's Hospital, London SW1.
}

The ideal solution is to have an indwelling arterial $\mathrm{Po}_{2}$ sensor which is inexpensive and will minimize blood sampling. We have published preliminary data on such a system using a Galvanic electrode (Parker et al., 1971; Goddard et al., 1972), and an indwelling polarographic oxygen electrode has recently been described for use in the newborn (Harris and Nugent, 1973). In the latter system the standard error of $\mathrm{PaO}_{2}$ from the predicted value was 18.8 torr and problems of drift and nonlinearity at high $\mathrm{PaO}_{2}$ ranges were noted.

Experience of using our system in newborn babies with the respiratory distress syndrome has satisfied us of the clinical value of knowing the immediate effect on $\mathrm{PaO}_{2}$ of various manoeuvres-both therapeutic, such as CPAP, or accidental, such as unplanned changes in the oxygen supply.

\section{Cell construction and operation}

The cell is basically that designed and described by Parker et al. (1971), but a number of modifications have been made to overcome practical difficulties with the original assembly.

The transducer consists of a Galvanic type cell as described by Hersch (1952a, b) surrounded by a thin gas-permeable membrane, similar to that used by Mancy, Okun, and Reilley (1962) and micro-miniaturized so that it can be assembled in the tip of a 5 FG catheter. An oxygen concentration gradient exists across the gas-permeable membrane and the oxygen is then electrolytically 
reduced at the cell cathode to produce a flow of electrons in an external circuit. The reaction of the cell is such that the oxygen tension at the silver surface is maintained at zero and therefore in the presence of different oxygen tensions corresponding currents will be generated by the cell achieving this zero tension. Thus, this current is proportional to the oxygen tension outside the membrane. Lead hydroxide is deposited on the anode as the reduction process proceeds, and it is this formation which eventually brings the cell action to an end.

The form of the transducer employed for this study is shown in Fig. 1. A silver cathode is fixed

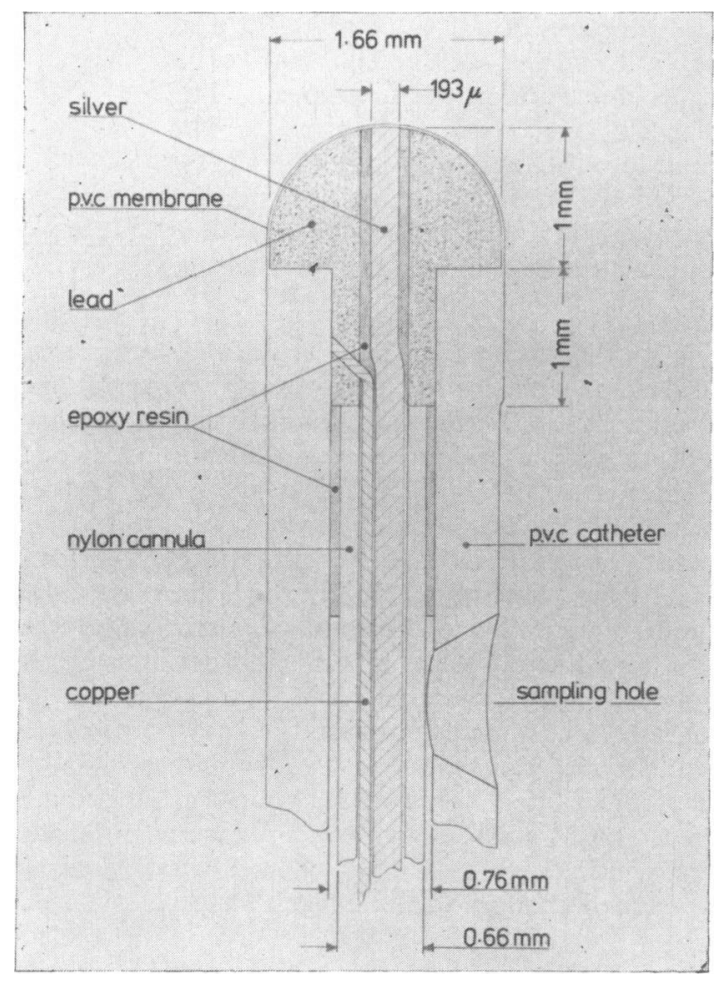

FIG. 1.-Diagram of catheter tip transducer.

coaxially within a domed cylindrical lead anode by means of epoxy resin (Araldite* type AY 105 with HY 972 hardener, Key, Parker, and Davies, 1970) and a copper wire is attached to the lead anode. The silver and copper wires are sheathed within a fine nylon cannula and the whole assembly is then glued to the end of a polyvinyl chloride (PVC) FG5 catheter. This leaves a narrow cylindrical sampling

*Ciba-Geigy (U.K.) Ltd. lumen within the FG5 catheter. The silver and copper wires leave the FG5 catheter near its distal end through a hole in the side wall sealed with epoxy resin and are connected to a miniature electrical plug.

The lead tip is etched with dilute sulphuric acid, washed in distilled water, dried, and then dipped into a saturated solution of potassium chloride. A fine coating of crystals is deposited on the tip as the electrolyte evaporates, but the etching helps to reduce the size of the crystals thus formed. The membrane is formed using a dip-coating method developed by D. Parker (personal communication, 1971). The lead tip and terminal $2 \mathrm{~mm}$ of the PVC catheter are lowered into a solution of PVC in cyclohexanone of constant viscosity and temperature and withdrawn at a constant rate in an attempt to produce membranes of constant thickness. The PVC membrane thus formed over the cell is chemically bonded to the supporting catheter, which virtually eliminates any risk of dislodging the membrane. Activation of the cell is achieved by steaming the tip of the transducer for approximately 30 seconds when water vapour diffuses through the membrane and dissolves the potassium chloride. The catheter is packed with its transducer tip immersed in a water jacket, and is gamma sterilized and stored until required. Storing the cell in water allows the cell membrane to absorb as much water as it can and this to some extent stabilizes the subsequent response of the transducers when used in a baby. The cell output current is directly proportional to the partial pressure of oxygen and the transducers produce $0.6-1 \cdot 8 \mathrm{nA} / 10$ torr $\mathrm{O}_{2}$ at $37{ }^{\circ} \mathrm{C}$. The output of the transducers varies with the membrane thickness, which we try to keep constant. The transducer output increases 3\% for each degree centigrade temperature rise due to the membrane permeability temperature coefficient and this varies for each transducer. No attempt has been made to compensate for it, though investigation is in progress to provide automatic temperature compensation. The output is not affected by change of flow, pressure, or $p \mathrm{H}$ in the range found in the neonatal aorta. An increase of 10 torr in $\mathrm{PaCO}_{2}$ increased the output by $0.9 \%$.

The cell may be considered to be a current generator, having an internal impedance of approximately $40 \mathrm{M} \Omega$, and should therefore be fed into a very low input impedance amplifying system. Electrical safety considerations make it necessary to employ isolated amplifier techniques (Pocock, 1972; Dobbie, 1972). The system developed for use with babies consists of an isolated first stage, feeding a digital display with provision for a pen recorder 
output. A calibration control consisting of a ten-turn dial adjusts the gain of the amplifier, and to simplify setting up the recorder, zero and any arbitrary full-scale reading may be selected with push buttons.

\section{Calibration}

Because of the gradual change in sensitivity caused by membrane thickening due to water absorption, and because of the existence of an unpredictable difference in sensitivity in blood and saline, it is essential to calibrate the cell in vivo. The transducer is connected to the amplifier before insertion to ensure that it is functioning. Approximately 15 minutes are allowed in vivo for stabilization and then a blood sample is drawn through the catheter, the digital display being read at the moment of sampling. The $\mathrm{Po}_{2}$ of the sample is measured with a standard blood gas analyser. On the basis of this value and the digital display reading, a calibration factor for the cell is determined and this is set directly into the amplifier calibration dial. Subsequent blood samples are taken 4- to 6-hourly and a new calibration factor calculated if necessary.

\section{In vivo experiments}

An initial series of experiments was carried out on rabbits anaesthetized with intravenous phenobarbitone $30 \mathrm{mg} / \mathrm{kg}$. The transducer catheter was inserted into one femoral artery such that its tip was located in the abdominal aorta. As earlier transducers had no sampling lumen a catheter was inserted into the opposite femoral artery to allow for continuous monitoring of pulse and blood pressure and for blood sampling. After calibration the animals breathed varying oxygen concentrations via a face mask. Blood samples were taken when the $\mathrm{Po}_{2}$ readout from the transducer had stabilized. In 3 animals the experiment was terminated after 3 to 6 hours, but a further 3 animals were allowed to recover from the anaesthetic and further readings were taken at intervals during the subsequent 36 hours, after which current output from the transducer began to decline; in one of these there was no necessity for any calibration change throughout the experiment but in the other 2 there was a gradual fall in current output during the first 3 hours of use before stability was achieved.

Fig. 2 shows the cumulated results of these experiments. After the transducer had been calibrated the correlation between $\mathrm{PaO}_{2}$ values obtained from the withdrawn aortic blood and the reading from the transducers was $0.987(P<0.001)$. Blood lead values were measured in 3 animals before

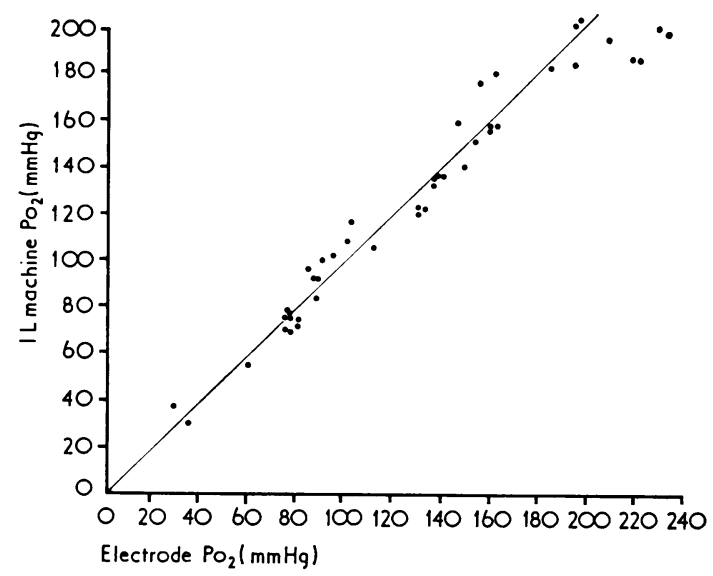

FIG. 2.-Correlation between readout $\mathrm{PaO}_{2}$ and $\mathrm{PaO}_{2}$ on a sample of withdrawn blood. 43 readings from 6 rabbits (6-10 readings/animal).

and after insertion of the catheter and no change occurred.

\section{Experience in newborn babies}

Transducers have been used in 8 infants: in Case 8 the first catheter did not work and was then replaced by another which did function. Two other babies were catheterized but the procedure was abandoned as blood could never be withdrawn through the sampling lumen. The catheters were inserted into the umbilical artery and positioned with their tip at about the level of the diaphragm. The position was checked radiographically. No more difficulty was experienced than usual with umbilical arterial catheterization, and in fact the slightly increased rigidity of the catheter may have made the procedure somewhat easier.

\section{Methods}

The management of the infant was that of routine intensive care. The baby was nursed naked between 36 and $36.5{ }^{\circ} \mathrm{C}$. Blood samples were withdrawn through the catheters 4- to 6-hourly to check the calibration and for blood gas analysis. $\mathrm{PaO}_{2}, \mathrm{pH}$, and $\mathrm{PaCO}_{2}$ were measured on an IL 313 Blood Gas Analyser (Instrumentation Laboratories Inc.). The catheters were constantly perfused with heparinized saline 10 $\mu \mathrm{m} / \mathrm{ml}$ at $0.5 \mathrm{ml} / \mathrm{hr}$ with the object of preventing clotting in the sampling lumen. Bicarbonate was given when necessary to maintain $p \mathrm{H}$ greater than $\mathbf{7 \cdot 2 5}$. Enough oxygen was given to maintain the babies $\mathrm{PaO}_{2}$ in the range of $60-80$ torr. If more than $60 \% \mathrm{O}_{2}$ was required, constant positive airways pressure (CPAP) was used, given either by endotracheal tube or a head box (Gregory et al., 1971). 


\begin{tabular}{|c|c|c|c|c|c|}
\hline Case no. & $\begin{array}{l}\text { Weight } \\
(\mathrm{g})\end{array}$ & $\begin{array}{l}\text { Gestational age } \\
\text { (wk) }\end{array}$ & Diagnosis & Outcome & $\begin{array}{l}\text { 음 } \\
\frac{\bar{\sigma}}{\bar{\sigma}} \\
\frac{\bar{D}}{0}\end{array}$ \\
\hline 1 & 2660 & 40 & RDS & Survived & $\frac{2}{2}$ \\
\hline 2 & 1880 & 33 & $\begin{array}{l}\text { RDS } \\
\text { HDN }\end{array}$ & Survived & $\vec{\omega}$ \\
\hline 3 & 1700 & 32 & $\begin{array}{l}\text { RDS } \\
\text { CPAP } \\
\text { IPPV }\end{array}$ & Survived & $\overrightarrow{\vec{\omega}}$ \\
\hline 4 & 1040 & 30 & $\begin{array}{l}\text { RDS; liver haematoma; } \\
\text { subdural haemorrhage; } \\
\text { CPAP-IPPV }\end{array}$ & Died & $\frac{0}{2}$ \\
\hline 5 & 1340 & 31 & $\begin{array}{l}\text { RDS } \\
\text { CPAP }\end{array}$ & Survived & cै \\
\hline 6 & 2170 & 33 & RDS & Survived & $\vec{z}$ \\
\hline 7 & 1150 & 29 & $\begin{array}{l}\text { RDS } \\
\text { CPAP }\end{array}$ & Survived & $\begin{array}{l}\infty \\
\omega \\
0 \\
0\end{array}$ \\
\hline 8 & 1650 & 29 & $\begin{array}{l}\text { RDS } \\
\text { CPAP }\end{array}$ & Survived & $\vec{z}$ \\
\hline
\end{tabular}

Two babies were ventilated because of apnoea. In most cases respirations were recorded simultaneously using either an impedance pneumograph (Air Shields Apnoea Monitor) or a magnetometer (Magnetometer Apnoea Monitor; Rolfe, 1971, 1972). Heart rate was monitored using either Air Shields heart rate meter or a Devices ECG. Blood pressure was recorded in 2 babies via the saline-filled sampling lumen using a Cambridge PT8 transducer which has a low volume displacement allowing comparatively high frequency measurements through small bore catheters. All the data, including $\mathrm{PaO}_{2}$, were recorded simultaneously on either a Devices M 19 or M 8 recorder.

\section{Results}

The clinical details of the 8 babies in whom the catheters were used are given in the Table. The longest time a catheter worked satisfactorily was for 103 hours. In 5 of the 8 cases the transducer was still working satisfactorily when blockage of the sampling lumen necessitated catheter removal: in Case 1 the catheter was removed while still functioning when the baby had made a rapid recovery from his respiratory distress.

The comparatively long response time of the catheters can be seen, and in the cases where the catheter was tested after removal the response time was even more prolonged. In vitro measurements of the 0 to $95 \%$ response time were made by subjecting the cells to step changes in $\mathrm{Po}_{2}$. This was achieved using a 3-way tap arrangement which could select pressurized supplies of blood equilibrated at different $\mathrm{PO}_{2}$ values. Nevertheless, the catheters have proved particularly valuable in certain specific situations.

Effect of CPAP or IPPV. In 5 babies (Cases 3, $4,5,7$, and 8 ) it was possible to detect the rapid rise in $\mathrm{PaO}_{2}$ when CPAP was begun. All these patients had very irregular respirations as shown by the impedance pneumograph before starting CPAP. However, when the $\mathrm{PaO}_{2}$ began to rise there followed a marked regularization of the respiration rate (Fig. 3). The respiration rate could also increase before the $\mathrm{PaO}_{2}$ rose (Fig. 4).

Effect of radial artery puncture. In 3 babies (Cases 2, 3, and 6) radial artery punctures were carried out to attempt $\mathrm{PaO}_{2}$ calibration when the sampling lumen had blocked. On three occasions the $\mathrm{PaO}_{2}$ fell considerably during the procedure (Fig. 5). On one other occasion the $\mathrm{PaO}_{2}$ remained steady. 2 babies were receiving oxygen by head box and opening the incubator ports therefore would not lessen the $\mathrm{FiO}_{2}$.

Oxygen leak. In one infant (Case 3) a leak developed in the oxygen supply system and the first indication of this was a rapidly falling value on the transducer digital readout. This lead to a prompt identification of the leak. 


\section{8 catheterized infants}

\begin{tabular}{|c|c|c|c|c|c|}
\hline \multirow{2}{*}{$\begin{array}{l}\text { Age catheter } \\
\text { inserted } \\
(\mathbf{h r})\end{array}$} & \multirow{2}{*}{$\begin{array}{l}\text { Duration catheter } \\
\text { in situ } \\
\text { (hr) }\end{array}$} & \multirow{2}{*}{$\begin{array}{l}\text { Duration sampling } \\
\text { possible } \\
\text { (hr) }\end{array}$} & \multicolumn{2}{|c|}{ Response time } & \multirow{2}{*}{ Comment on electrode } \\
\hline & & & $\begin{array}{l}\text { Before } \\
\text { (sec) }\end{array}$ & $\begin{array}{l}\text { After } \\
(\mathrm{sec})\end{array}$ & \\
\hline 11 & 13 & 13 & 12 & & $\begin{array}{l}\text { Working satisfactorily when } \\
\text { removed }\end{array}$ \\
\hline 4 & 29 & 26 & 15 & & $\begin{array}{l}\text { Working satisfactorily when } \\
\text { removed; blocked }\end{array}$ \\
\hline 5 & 18 & 16 & 20 & & $\begin{array}{l}\text { Decreasing output at time of } \\
\text { removal; blocked }\end{array}$ \\
\hline 1 & 27 & 27 & & & Membrane failure \\
\hline 1 & 108 & 103 & 15 & 45 & $\begin{array}{l}\text { Working satisfactorily when } \\
\text { removed; blocked }\end{array}$ \\
\hline $2 \frac{1}{2}$ & 19 & 7 & 27 & 40 & $\begin{array}{l}\text { Working satisfactorily when } \\
\text { removed; blocked }\end{array}$ \\
\hline 1 & 24 & 24 & 28 & 43 & $\begin{array}{l}\text { Electronic failure distal to } \\
\text { catheter; (anode connexion } \\
\text { broken at catheter/connector } \\
\text { junction) }\end{array}$ \\
\hline 6 & 26 & $22 \frac{1}{2}$ & 16 & 30 & $\begin{array}{l}\text { Working satisfactorily when } \\
\text { removed; blocked }\end{array}$ \\
\hline
\end{tabular}

IPPV, intermittent positive pressure ventilator.

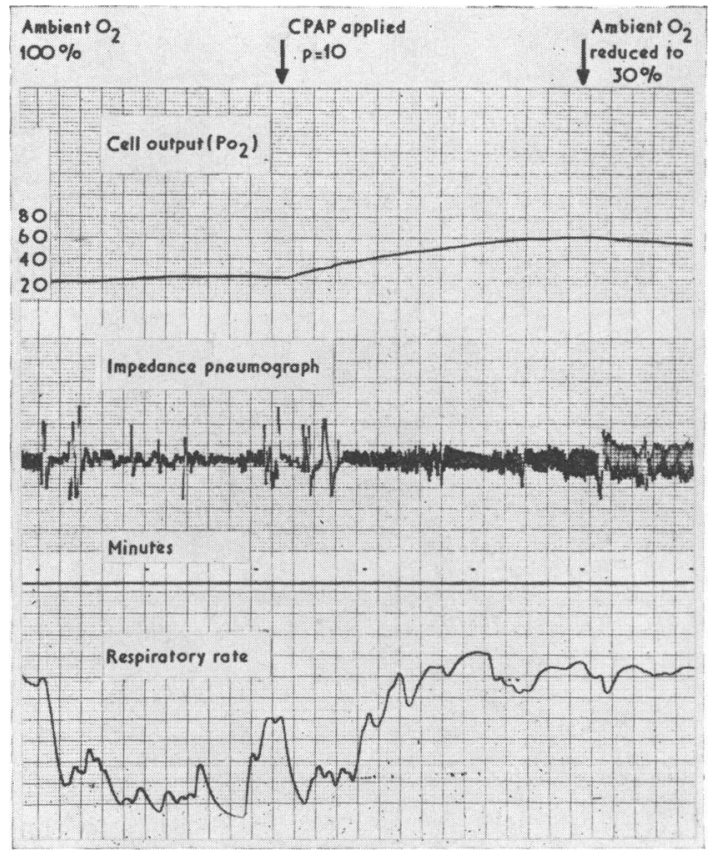

FiG. 3.-Effect of starting distending pressure: improvement in $\mathrm{PaO}_{2}$ before improvement in respiratory pattern.
Blood pressure monitoring. Using the small displacement transducer it was possible in 2 babies (Cases 5 and 7) to monitor aortic blood pressure through the sampling lumen of the catheter.

Bicarbonate therapy. The effect of infusion was observed in 4 babies (Cases 2, 3, 4, and 8). No significant change in $\mathrm{PaO}_{2}$ took place.

Exchange transfusion. In 2 infants (Cases 2 and 5) exchange transfusion was carried out through an indwelling umbilical venous catheter. In Case 5 this was carried out to raise haematocrit. With the electrode catheter in situ, it was possible in these babies to monitor the $\mathrm{PaO}_{2}$ during the procedure. No changes occurred in Case 5. In Case 2, however, who was exchanged for rhesus incompatibility, it was noted that the $\mathrm{PaO}_{2}$ fell 5 to 10 torr with each injection of blood. This might have represented the effect of cold blood on the temperature-sensitive transducer tip rather than a true fall in $\mathrm{PaO}_{2}$, since the donor blood was not warmed; however, the temperature at which it was being injected was not known, nor can we estimate the dilution of the bolus injected on the ongoing cardiac output.

\section{Discussion}

The use of continuous recording $\mathrm{PaO}_{2}$ catheters was undoubtedly of great help in the clinical intensive care of these 8 babies. They gave early 


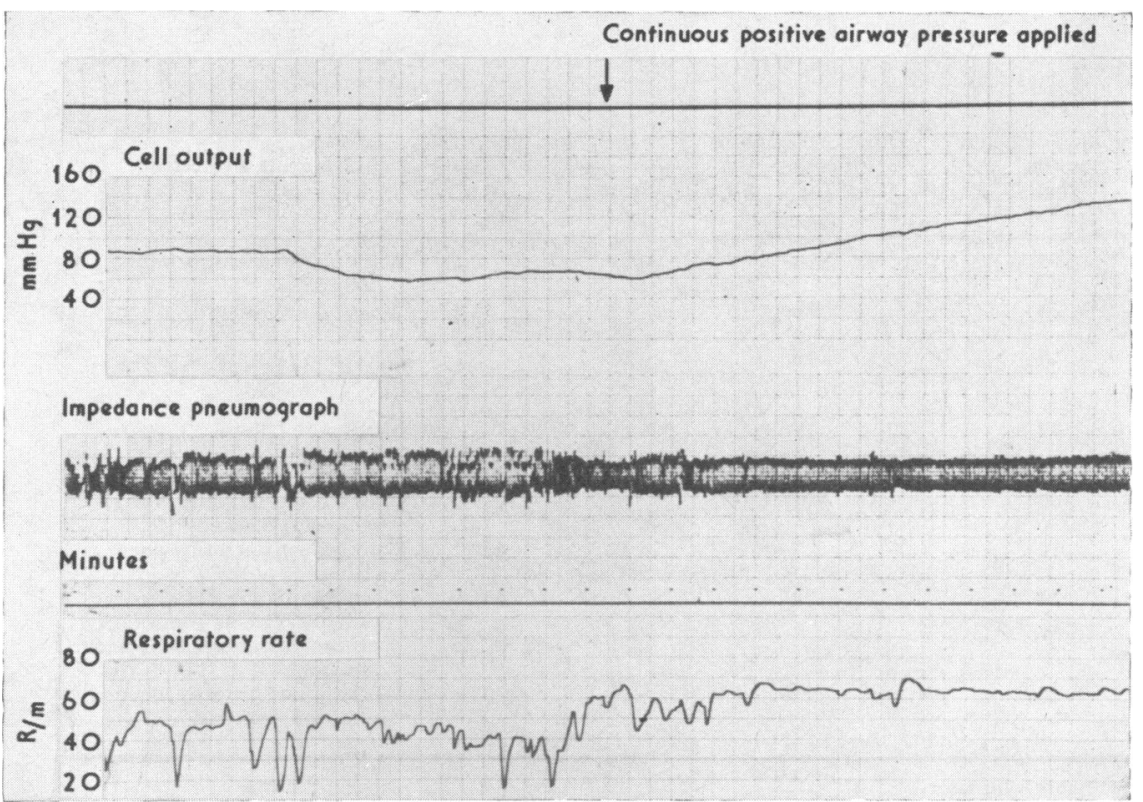

FIG. 4.-Effect of starting distending pressure: improvement on respiratory pattern before rise in $\mathrm{PaO}_{2}$.

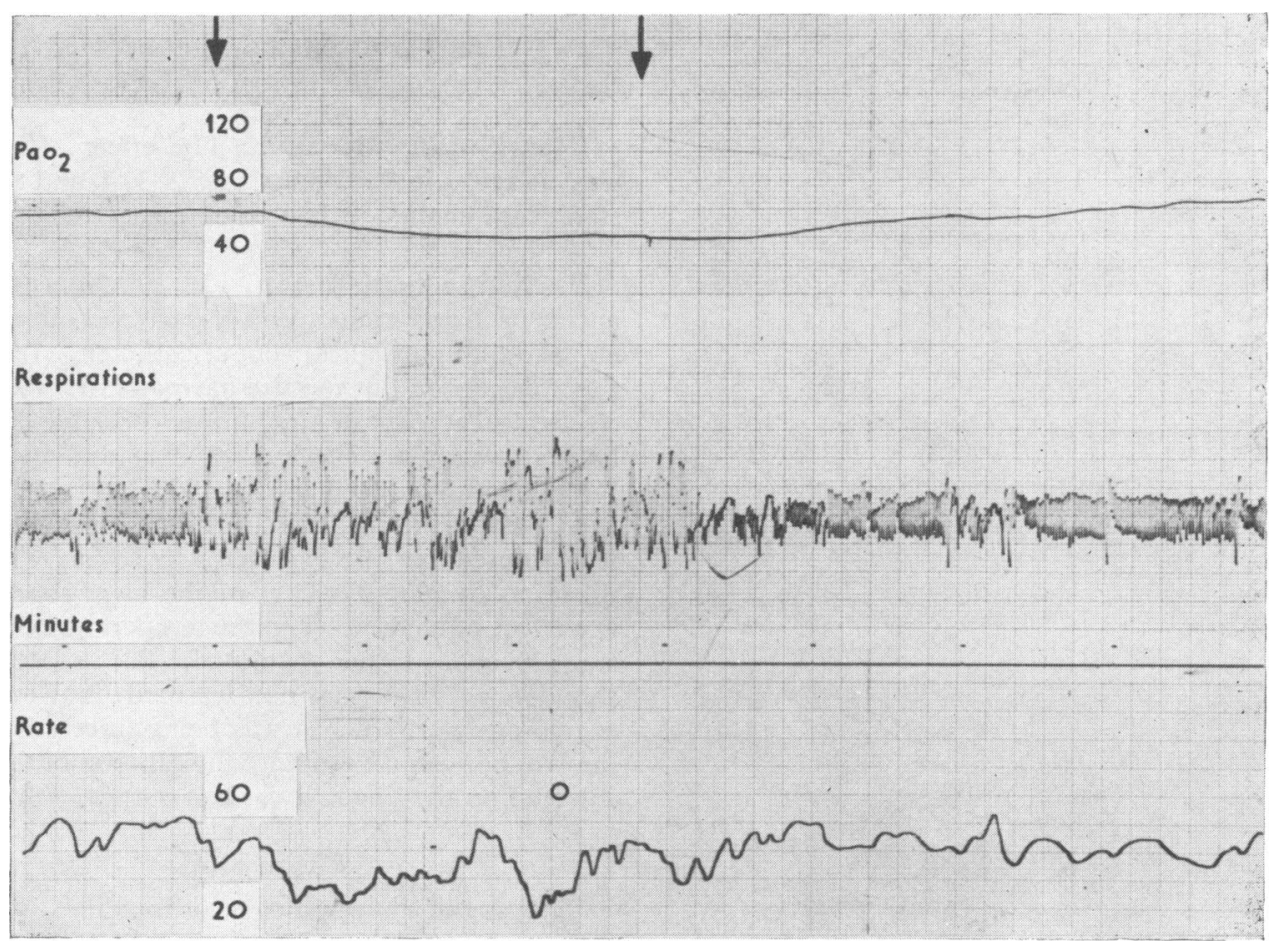

Frg. 5.-Fall in $\mathrm{PaO}_{2}$ and irregularity of respirations during attempted radial artery stab. 
warning of clinical deterioration and provided a continuous guide to the infant's condition at rest and during procedures such as exchange transfusion. They were particularly useful during adjustments in oxygen therapy, when the changes in the transducer readout showed whether the treatment was having the desired effect. We estimated that this led to at least a halving of the number of blood samples withdrawn for conventional blood gas analyses during the acute phase of the illness.

Since the output from the cells varies during the time they are in situ, the $\mathrm{PaO}_{2}$ calibration needs to be checked 4-hourly. In 57 simultaneous blood gas analyses and catheter readouts the difference in $\mathrm{PaO}_{2}$ was more than $25 \%$ on 8 occasions; in 6 this occurred in Case 5, where the transducer was persistently difficult to calibrate. However, in the other cases, particularly during the period when the cell output was stable after the initial calibration, the readout and the $\mathrm{PaO}_{2}$ of the withdrawn sample was within the limits of error of blood gas analysis systems. We do not feel that the fall in output once the catheter has been in situ some time is dangerous since no changes in $\mathrm{O}_{2}$ therapy based on falling $\mathrm{PaO}_{2}$ readout are made by the nursing staff without prior consultation with the resident medical staff.

Blood has to be withdrawn for acid-base investigations and biochemical investigations in addition to the periodic calibration check. Thus, a sampling facility is essential and is one of the major problems still to be solved in the design of the transducers. Despite continuous infusions of heparinized saline using a constant infusion pump, 5 out of the 8 babies had to have their catheters removed because the sampling lumen was blocked when the transducer was still working. Attempts to check the $\mathrm{PaO}_{2}$ by peripheral arterial puncture were not satisfactory since the $\mathrm{PaO}_{2}$ fell when the baby was handled and a steady state could not be obtained (Fig. 5). These data cast overall doubt on the validity of peripheral arterial punctures for blood gas analysis in any situation in the sick newborn baby. It is certainly well recognized that sick neonates may become cyanosed on handling, though the mechanism of this is not understood.

The catheters we used had response times of 12 to 18 seconds before insertion and 30 to 45 seconds after removal. This increase is due to the hygroscopic properties of the PVC which swells while in contact with plasma water. This not only increased the thickness of the membrane, but also widened the electrolyte layer between the membrane and cathode, further prolonging the response time. Though the lengthy response time does not limit the clinical use of these transducers, it does limit their research application. Therefore PVC is not the best material for the membrane and we are hoping to use polyethylene in the future, which will give a much faster response time, though the secure attachment of such membranes presents practical problems.

Like Harris and Nugent (1973), we feel that this system is at present suitable only for special care baby units where staffing and facilities are sufficient to allow personnel to become proficient in the use of these transducers. However, their development must provide more satisfactory monitoring of oxygen therapy than is at present available.

We thank Professor J. P. M. Tizard for his help in preparing this paper; the Sir William Coxen Fund for providing facilities; the Department of Medical Physics, Royal Postgraduate Medical School, Hammersmith Hospital, for provision of facilities for developing the transducer; and Misses M. E. Castle and P. Townshend and the nursing staff of the premature baby units in Hammersmith and Oxford for looking after the babies.

\section{REFBRENCES}

Banerjee, C. K., Girling, D. J., and Wigglesworth, J. S. (1972). Pulmonary fibroplasia in newborn babies treated with oxygen and artificial ventilation. Archives of Disease in Childhood, 47, 509.

Chernick, V., and Vidyasagar, D. (1972). Continuous negative chest wall pressure in hyaline membrane disease. Pediatrics, 49, 753.

Davies, P. A., Robinson, R. J., Scopes, J. W., Tizard, J. P. M., and Wigglesworth, J. S. (1972). Medical Care of Newborn Babies, p. 107. Spastics International Medical Publications No. 44/45. Heinemann, London.

Dobbie, A. K. (1972). Electricity in hospitals. Biomedical Engineering, 7, 12.

Dunn, P. M., Speidel, B. D., and Storrs, C. N. (1973). In defence of the Gregory Box. Lancet, 2, 853.

Fanaroff, A. A., Cha, C. C., Sosa, R., Crumrine, R. S., and Klaus M. H. (1973). Controlled trial of continuous negative external pressure in the treatment of severe respiratory distress syndrome. Fournal of Pediatrics, 82, 921.

Goddard, P., Keith, I., Marcovitch, H., Rolfe, P., and Scopes, J. W. (1972). Experience with a catheter tip transducer for continuous measurement of blood oxygen tension, including evaluation in 4 newborn babies. (Abst.) Archives of Disease in Childhood, 47, 675.

Gregory, G. A., Kitterman, J. A., Phibbs, R. H., Tooley, W. H., and Hamilton, W. K. (1971). Treatment of the idiopathic respiratory-distress syndrome with continuous positive airway pressure. New England fournal of Medicine, 284, 1333.

Harris, T. R., and Nugent, M. (1973). Continuous arterial oxygen tension monitoring in the newborn infant. Fournal of Pediatrics, $82,929$.

Hersch, P. (1952a). Electrochemical gas analysis. The Chemical Age, 67, 565.

Hersch, P. (1952b). An electrochemical method of gas analysis. Industrial Chemist, 28, 488.

Key, A., Parker, D., and Davies, R. (1970). Use of epoxy resin in oxygen electrodes. Physics in Medicine and Biology, 15, 569.

Mancy, K. H., Okun, D. A., and Reilley, C. N. (1962). A galvanic cell oxygen analyzer. Fournal of Electroanalytical Chemistry, 4, 65.

Parker, D., Key, A., Davies, R., Scopes, J. W., and Marcovitch, J. (1971). A disposable catheter tip transducer for continuous measurement of blood oxygen tension in vivo. Biomedical Engineering, 6, 313.

Pocock, S. N. (1972). Earth-free patient monitoring. Biomedical Engineering, 7, 21.

Roberton, N. R. C., Gupta, J. M., Dahlenburg, G. W., and Tizard, J. P. M. (1968). Oxygen therapy in the newborn. Lancet, 1, 1323. 
Rolfe, P. (1971). A magnetometer respiration monitor for use with premature babies. Biomedical Engineering, 6, 402.

Rolfe, P. (1972). The use of magnetometer respiration monitor with premature infants. Proceedings of the Biomedical Engineering Congress, Session 2, Milan.

Scopes, J. W. (1971). Respiratory distress syndrome. In Recent Advances in Paediatrics, 4th ed., p. 81. Ed. by D. Hull and D. M. T. Gairdner. Churchill, Edinburgh and London.
Veasey, L. G., Clark, J. S., Jung, A. L., and Jenkins, J. L. (1971). A system for computerized automated blood gas analysis. Its use in newborn infants with respiratory distress. Pediatrics, 48, 5.

Correspondence to Dr. N. R. C. Roberton, Department of Paediatrics, John Radcliffe Hospital, Headington, Oxford OX3 9DU.

\section{Corrigendum}

On page 473 of the June issue in 'Matched development of a pair of monozygous twins of grossly different size at birth' by J. M. H. Buckler and A. Robinson, Archives, 1974, 49, 472, under 'Initial progress', the second paragraph should read:

'Over the course of the first year, the smaller twin caught up her larger sister rapidly. At 14 weeks the weights of twins A and B were $5 \cdot 78$ and $4.54 \mathrm{~kg}$, and at $11 \frac{1}{2}$ months 7.94 and $7 \cdot 63 \mathrm{~kg}$, respectively.' 